\section{Alterations of social behavior in rats and hamsters following lesions of the septal forebrain*}

\section{DAVID A. JOHNSON, ALEX POPLAWSKY, and LINAS BIELIAUSKAS Ohio University, Athens, Ohio 45701}

Septal lesions alter the nature of social behavior in rats and hamsters. Rats were hyperemotional and more gregarious (contact time) in the open field following septal lesions. Hamsters were neither hyperemotional nor more gregarious after septal lesions. A marked increase in number of aggressive encounters was observed between hamsters.

Recent evidence has suggested an important role of the septal nucleus in the mediation of social behavior. Brady \& Nauta (1953) reported that septal lesions resulted in increased aggressive behavior and hyperemotionality in the rat. Jonason \& Enloe (1971) found that rats with septal damage were more socially cohesive, spending more time together in the open field than either amygdaloid or control lesioned rats. The observed alteration in the social behavior of rats following septal lesions has also been confirmed. Rats receiving septal lesions spent more time in direct physical contact (Enloe, Jonason, Jonason, \& Meyer, 1971; Johnson, 1971). Submissive postures in one member of each rat pair increased following septal lesions. This might partially explain the increase in contact time observed by Enloe et al (1971).

Septal ablation of the hamster has not always produced the same results as seen in rats. Hyperemotionality was not observed in the septal hamster (Sodetz, Matalka, \& Bunnel, 1967); however, CAR acquisition was facilitated for hamsters after receiving septal lesions (Matalka \& Bunnel, 1968). Sodetz \& Bunnel (1970) have reported that septal ablation in the hamster increased aggressive social responding of both socially inexperienced and experienced animals. The present study was designed to compare the social cohesiveness in conspecific pairs of rats and hamsters before and after both animals of a pair had received septal lesions.

\section{SUBJECTS}

Twenty male golden hamsters and 14 male Long-Evans hooded rats between the ages of 90 and 120 days were used as Ss. Each $\mathrm{S}$ was individually housed at the beginning of

*This research was supported by Ohio University Research Grant 0-21000-3660. The second authors were supported by an NSF predoctoral traineeship. the experiment and maintained on an ad lib food and water schedule. \section{APPARATUS}

The apparatus used was a circular open field similar to the one described by Latane (1970). The field, which was $4 \mathrm{ft}$ in diam and surrounded by an 18-in. wall painted glossy white, was situated in a well-lit room. A stopwatch was used to measure the number of seconds in direct physical contact.

\section{PREOPERATIVE PROCEDURE}

On the day before the animals were observed in pairs, each animal was placed alone in the open field for a 5-min habituation period. The animals were rated for emotionality on each testing day by the use of the procedures and scale described by King (1958). On Experimental Days 1.6, each animal pair was placed in the open field for a 5-min testing period. The amount of time spent in direct physical contact was recorded. In addition, every $15 \mathrm{sec}$, any aggression observed between the individuals in each hamster pair was recorded.

\section{SURGERY}

After the 6 days of preoperative testing, each animal was given a bilateral septal lesion. The appropriate lesion was accomplished pre-and postoperatively for rats and hamsters. stereotaxically by a unipolar electrode which was insulated except for $0.5 \mathrm{~mm}$ at the tip. De Groot (1959) coordinates for septal lesions in the rat were used (A $\cdot \mathrm{P}+7.8 \mathrm{~mm}$, $\mathrm{D} \cdot \mathrm{V}+1.0 \mathrm{~mm}, \mathrm{~L} \pm .5 \mathrm{~mm})$. The coordinates of the hamster lesions were established by pilot studies (A - P $+5.0 \mathrm{~mm}, \mathrm{D} \cdot \mathrm{V}+1.3 \mathrm{~mm}$, $\mathrm{L} \pm .5 \mathrm{~mm})$. An anodal current of $2.0 \mathrm{~mA}$ was passed for $15 \mathrm{sec}$ on both sides of the septum.

\section{POSTOPERATIVE PROCEDURE}

Following a 3 -day recovery period, each pair of Ss was observed in the open field for 8 consecutive days. On all days, emotionality ratings were taken before each pair was placed in the open field. Data on social behavior were collected by the preoperative procedures already described.

Upon completion of postoperative training, all animals were sacrificed and standard histological procedures were used to determine the placement and extent of damage caused by the lesions. Damage to the septal region ranged from $40 \%$ to $100 \%$ in all operated rats and hamsters. Damage to the corpus callosum, fornix, and caudate nucleus was minimal. \section{RESULTS}

The main results of the experiment are shown in Fig. 1, which gives the preoperative and postoperative contact times of both rats and hamsters. Analysis of variance indicated that the contact time of hamsters did not differ after the septal lesion, while the contact time of the rats was significantly greater $(\mathrm{F}=20.54$, $\mathrm{df}=1 / 12, \mathrm{p}<.01)$ after the septal lesion. The analyses of aggressive behavior during the 5-min testing period revealed that the septal lesions in hamsters resulted in a postoperative increase in number of aggressive encounters $(F=4.94, \quad \mathrm{df}=1 / 18$, $\mathrm{p}<.05)$.

Analysis of the emotionality scores revealed no significant differences between preoperative and

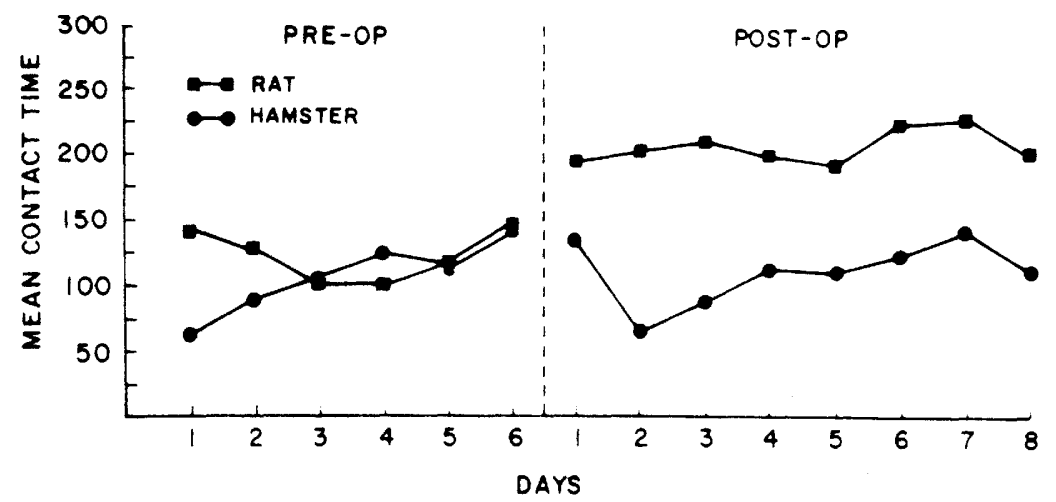

Fig. 1. Mean number of seconds spent in physical contact in the open field 
postoperative ratings of the hamsters; however, the emotionality scores of the rats were significantly higher following septal lesions $(F=20.42$, $\mathrm{df}=1 / 26, \mathrm{p}<.01)$.

$$
\text { DISCUSSION }
$$

Septal lesions did not produce an increase in social cohesiveness in hamsters as has been observed following septal lesions in rats. Instead, septal hamsters became more aggressive in social interaction. Septal lesions also resulted in differential effects on emotionality between rats (hyperemotional) and hamsters (no change).

Preoperatively dominant hamsters continued their dominance postoperatively. These animals also showed an increase in the number of aggressive encounters; however, these encounters were not maintained long enough to affect the time spent in direct physical contact. These results are in agreement with the findings of Sodetz \& Bunnel (1970). Enloe et al (1971) pointed out that enhanced social cohesiveness in rats may result from one member of each pair remaining submissive. Septal lesions affect the social behavior of both rats and hamsters. The type of change in social behavior resulting from a septal lesion, however, depends on the species of animal being studied.

\section{REFERENCES}

BRADY J, V., \& NAUTA, W. J. H. Subcortical mechanisms in emotional behavior: Affective changes following septal forebrain lesions in the albino rat Journal of Comparative \& Physiological Psychology, 1953, 46, 339-346.

De GROOT, J. The rat forebrain in stereotaxic coordinates. Verhandelingen Konenklyke Nederlandsche Akademie van Wetenschappen, Natuurkunde, 1959, $52,1-40$.

ENLOE, L. J., JONASON, K. R., JONASON, B. A., \& MEYER, D. R. The effects of septal and amygdaloid lesions on social postures of the rat. Paper presented at Midwestern Psychological Association, May 1971 (Detroit).

JOHNSON, D. A Recovery of function following septal lesions in the infant rat. Journal of Comparative \& Physiological Psychology, 1971, in press.

JONASON, K. R., \& ENLOE, L. J. Alterations in social behavior following septal and amygdaloid lesions in the rat. Journal of Comparative \& Physiological Psy chology, 1971, 75, 286-301.

KING, F. A. Effects of septal and amygdala lesions on emotional behavior and conditioned avoidance responding in the rat. Journal of Nervous \& Mental Disease, $1958,126,57-63$.

LATANE, B. Gregariousness and fear in laboratory rats. Journal of Experimental Social Psychology, 1970, 5, 61-69.

MATALKA, E. S., \& BUNNELL, B. N. Septal ablation and CAR acquisition in the golden hamster. Psychonomic Science, 1968, 12, 27-28.

SODETZ, F. J., \& BUNNELL, B. N. Septal ablation and the social behavior of the golden hamster, Physiology \& Behavior. $1970,5,79-88$.

SODETZ, F. J., MATALKA, E. S., \& BUNNELL, B. N. Septal ablation and affective behavior in the golden hamster. Psychonomic Science, 1967, 7, 189-190. 